\title{
ALGAL BIO-INDICATION IN ASSESSMENT OF HYDROLOGICAL IMPACT ON ECOSYSTEM IN WETLANDS OF “SLAVYANSKY RESORT”
}

\author{
Valentina KLYMIUK *, Sophia BARINOVA ** and Andrii FATIUKHA ***
}

* Department of Botany and Ecology, Donetsk National University, Schorsa Street 46, Donetsk, Ukraine, UA-83050, valentina_k@i.ua

** Institute of Evolution, Haifa University, Mount Carmel, Israel, IL-31905, barinova@reserch.haifa.ac.il

*** Donetsk Botanical Garden of the National Academy of Sciences of Ukraine, Il'icha Avenue 110, Donetsk, Ukraine, UA-83059, avfatyha@gmail.com

DOI: 10.1515/trser-2015-0048

KEYWORDS: phytoplankton, salinity, biodiversity, protected area, Ukraine.

\section{ABSTRACT}

Algal bio-indication is commonly used in water quality assessment but can also help in assessing the impact of hydrology on freshwater wetland ecosystems. We identified 350 species and infraspecific taxa of algae from nine taxonomic divisions (Cyanoprokaryota, Chrysophyta, Euglenophyta, Dinophyta, Xanthophyta, Cryptophyta, Bacillariophyta, Chlorophyta, Charophyta) in 121 phytoplankton samples collected between 2007-2013 from seven lakes in the wetlands of the Regional Landscape Park "Slavyansky Resort", Ukraine. The algal species richness and phytoplankton biomass decreased as water salinity increased. In turn the water salinity was influenced by the inflow of groundwater, karst fracture and by the alluvial water tributaries of a paleoriver that affects the formation processes of lake-spring sulphide mud from the resort, which is often used for therapeutic purposes.

ZUSAMMENFASSUNG: Die Algen-Bioindikation in der Bewertung hydrologischer Einflüsse auf Feuchtgebietsökosysteme im Landschaftspark "Slavyansky Resort”.

Die Bioindikation mittels Algen wird häufig für die Bewertung der Wasserqualität verwendet, sie kann jedoch auch in der Einschätzung der Auswirkungen hydrologischer Ereignisse in Feuchtgebieten von Süßwasserökosystemen von Nutzen sein. Es wurden 350 Arten und infraspezifische Taxa von Algen aus neun taxonomischen Einheiten (Cyanoprokaryota, Chrysophyta, Euglenophyta, Dinophyta, Xanthophyta, Cryptophyta, Bacillariophyta, Chlorophyta, Charophyta) in 121 zwischen 2007-2013 entnommenen Phytoplanktonproben identifiziert und zwar aus sieben Seen der Feuchtgebiete im Landschaftspark "Slavyansky Resort". Der Reichtum an Algenarten und Phytoplankton Biomasse verringerte sich mit dem steigenden Salzgehalt des Wassers. Dieser wird seinerseits durch den Zufluss von Grundwasser aus dem Karstbereich und aus Gewässerzuflüssen beeinflusst, die Entstehungsprozesse der Quell-Seen Sulphide des therapeutischen Schlamms im Resort beeinträchtigen.

REZUMAT: Evaluarea bio-indicaţiei algale a impactului hidrologic asupra ecosistemului acvatic din „Staţiunea Slavyansky”.

Algele bio-indicatoare sunt frecvent utilizate în evaluarea calității apei, dar, de asemenea, pot ajuta la evaluarea impactului asupra ecosistemului bazinelor hidrografice de apă dulce. Am întâlnit 350 de specii și taxoni infraspecifici de alge din nouă încrengături (Cyanoprokaryota, Chrysophyta, Euglenophyta, Dinophyta, Xanthophyta, Cryptophyta, Bacillariophyta, Chlorophyta, Charophyta) în 121 de probe de fitoplancton colectate între 2007-2013 din şapte lacuri din zonele umede ale Parcului Regional Peisagistic „Staţiunea Slavyansky”. Bogăția și biomasa fitoplanctonului scad odată cu creșterea salinităţii apei. Salinitatea apei este influențată de afluxul de apă subterană, fracturi carstice, şi afluenții care afectează procesele de formare a nămolului terapeutic sulfuric de lac-izvor din stațiune. 


\section{INTRODUCTION}

Salinity plays an important role in the formation of communities of aquatic organisms such as microalgae. Its influence is reflected both in the species composition, abundance and biomass of phytoplankton and subsequent decomposition of plant residues in water bodies in general and of wetlands in hot dry climate in particular. The species composition of algae and mineralized lakes relation is well-known (Hammer, 1986).

The presence of mud with therapeutic properties was an important factor in the creation of the Slayansky Resort, because of its value.

The formation of mud with therapeutic properties is a complex, multy-year process that takes place in waters with high salt content. For lake-spring sulphide muds, for example those found in the Slayansky Resort, Ukraine, factors such as composition and salinity of water entering the pond are much more important than climatic factors (Holopov et al., 2002). The composition of the water entering the wetlands park is influenced by salt-infused sediments of Permian age (from karst fracture under lakes Ripne, Veysove and Garache), and it should be noted that there are also two types of topographic relief in the study area - watershed plateaus with altitudes from 90 to $180 \mathrm{~m}$ a.s.l., and accumulative plains with I-II river terraces, known as Kazenyi Toretz and Sukhoy Toretz (Popkov et al., 2005).

The chemical composition of water generates the necessary conditions for the specific processes of decomposition of organic residues in different groups of bacteria. These bacteria enrich the biogenic components of mud, giving many of them high therapeutic activity levels. The organic residues often encourage the formation of microalgae, which are the primary producer in the ecosystem, although in some water bodies it can be zooplankton. It should be noted that the more massively developed the microalgae are, the more potential material is generated for the formation of therapeutic mud.

The algal diversity in the Regional Landscape Park "Slavyansky Resort” was formed through periodic desiccation as well as being influenced by various anthropogenic impacts, and has been studied sporadically since the second half of the 17th century and more regularly since 2007 by the current research team (Klymiuk and Barinova, in press; Lyalyuk and Klymiuk, 2011; Barinova et al., in press; Klymiuk et al., 2014). The aim of the present study is to determine the relationships of salinity levels in the wetlands of "Slavyansky Resort" with the microalgae species richness and biomass as a basis for understanding the formation of therapeutic mud.

\section{MATERIAL AND METHODS}

\section{Study area}

The regional landscape park "Slavyansky Resort", Ukraine, was created in 2006. Its purpose was for the preservation and thoughtful use of unique natural complexes and artificial plantations of parkland, and the development of recreational areas. The park is located in the northeastern part of the city Slaviansk in Ukraine. It covers 431 hectares and includes three resorts, an extensive park, a seasonal ornithological reserve "Priozerny", and natural "monuments" of national importance such as lakes Ripne and Slipne, which are sources of unique therapeutic mud and brine. It was given the Belgium Grand Prix award in 1907 for quality (Kurulenko and Tretyakov, 2008) (Fig. 1). 


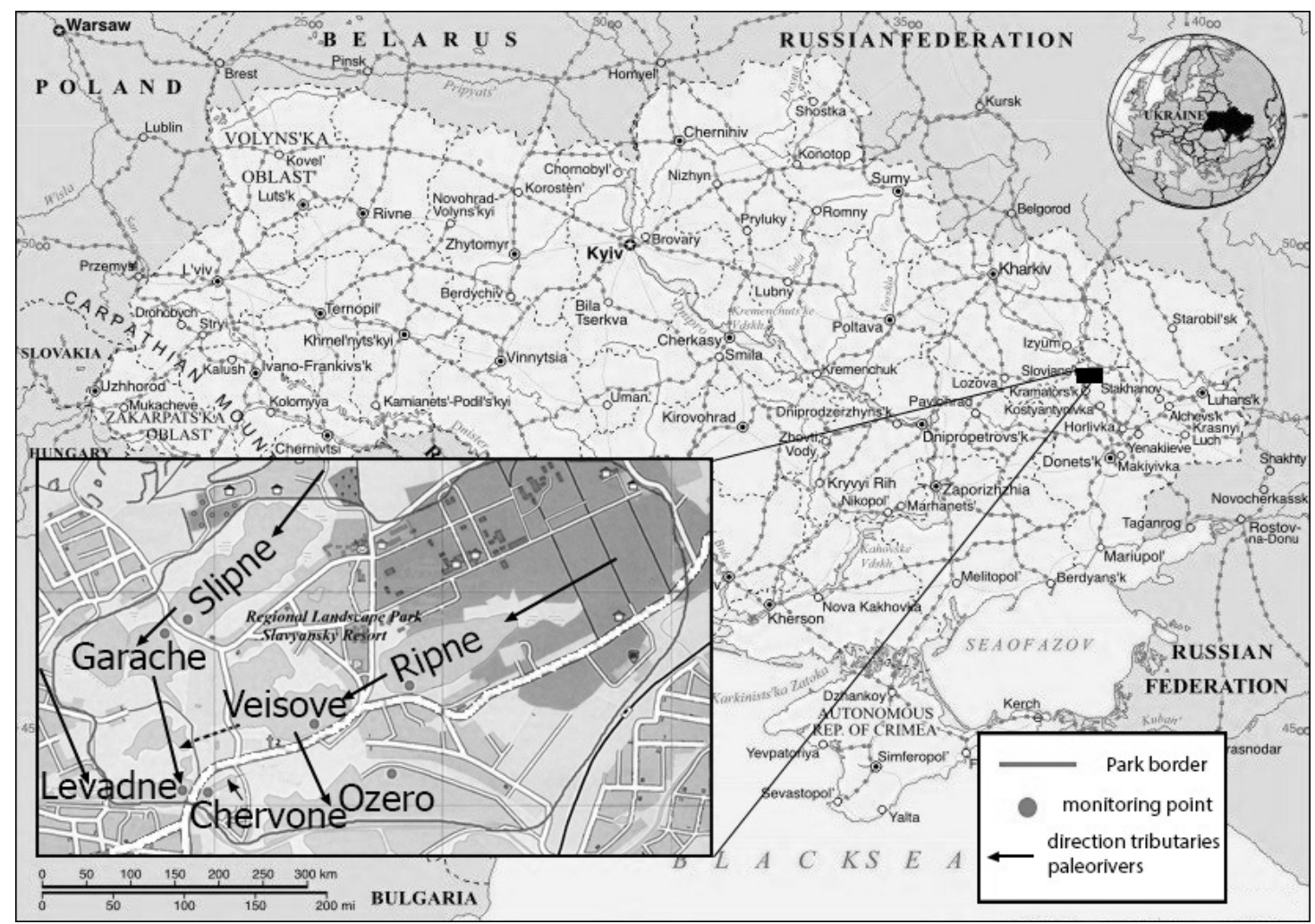

Figure 1: Map of the study site in the RLP "Slavyansky resort”.

Just inside the park are seven perennial lakes (Ripne, Veisove, Garache, Slipne, Levadne, Chervone, and an untitled lake informally named Ozero) and many temporary pools. The lakes are mostly of thermokarst origin, small, and shallow. The lakes are generally unconnected to each other, periodically dry up but can become briefly interconnected in spring following (heavy rainfall/snowmelt). It is impossible to trace the palaeoriver and its tributaries from the topographic profile. Sediments from the lakes are diverse, varying from sand to mud. Lake water color tends to be slightly yellow or colorless with a $\mathrm{pH}$ range of 6.3-8.0, and a conductivity range of $1.31-11.26 \mathrm{mSm} / \mathrm{cm}$. Depth of the lakes is generally shallow (about 0.5-2.5 m) with lake Ripne being the deepest at $8.5 \mathrm{~m}$. The lakes contain a unique community of organisms, including algae, which are the basis of the formation of therapeutic mud. In lake Ripne there is industrial fishing for mud and brine mud baths for the Slavyansky Resort - one of the oldest mud-bath resorts in Ukraine.

\section{Sampling and laboratory study}

The studied material comes from samples collected monthly during 2007-2013 from lakes Ripne, Veisove, Garache, Slipne, Levadne, Chervone, and Ozero. Phytoplankton was collected in the littoral and profundal zones. A sample volume was of $2 \mathrm{l}$ was collected and concentrated by accumulation on membrane filters "Vladipor" no. 7, or via a 10-20 l sample which was concentrated using a plankton net number 77 . Algae were studied alive and in fixed (using 4\% formaldehyde solution) states, using light microscopes MBI-3 and Micros MC 50 (Austria) with a magnification of 40X-90X (with immersion). Identification of algal species was performed using an international series of determinants of marine and freshwater algae species. Conductivity was analyzed with ionometric methods following Globan (1987). 


\section{RESULTS}

Altogether 334 species of algae (350 species and infraspecific taxa) from nine taxonomic Divisions (Cyanoprokaryota, Euglenophyta, Chrysophyta, Dinophyta, Xanthophyta, Cryptophyta, Bacillariophyta, Chlorophyta, and Charophyta) were recorded by our sampling (238 species and infraspecies), a finding supported by existing literature on the resort (Klymiuk et al., 2014; Tsarenko et al., 2006, 2009).

Changes in the measured chemical and biological variables in different lakes downstream of the tributaries of the paleoriver were plotted against water conductivity, the number of species, and the biomass of phytoplankton (Figs. 2 and 3). These figures demonstrate that conductivity increases from lake Ripne across lake Veisove to lake Ozero, indicating the course of the left tributary of the palaeoriver underneath these three lakes. The central and right tributaries of the paleoriver can be mapped in the changes in conductivity from lake Slipne, across lake Garache to lake Levadne.

The lakes Ripne, Veisove, Garache, Slipne, Levadne and Ozero have a gradient of conductivity. On average in each lake the conductivity varied between $6.6 \mathrm{mSm} / \mathrm{cm}$ and $11 \mathrm{mSm} / \mathrm{cm}$ (Figs. 2 and 3). The number of algal species detected in the same time period (January 2013 to May 2013) in the lake communities ranged from 30 to 75 (Figs. 2a and 2b).

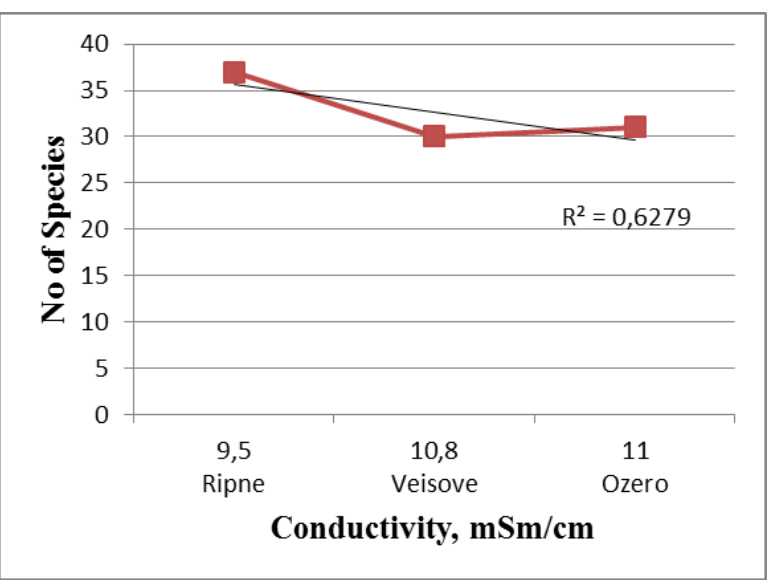

Figure 2a: Relationships between species numbers and water conductivity in the lakes: A - Ripne, Veisove, Ozero.

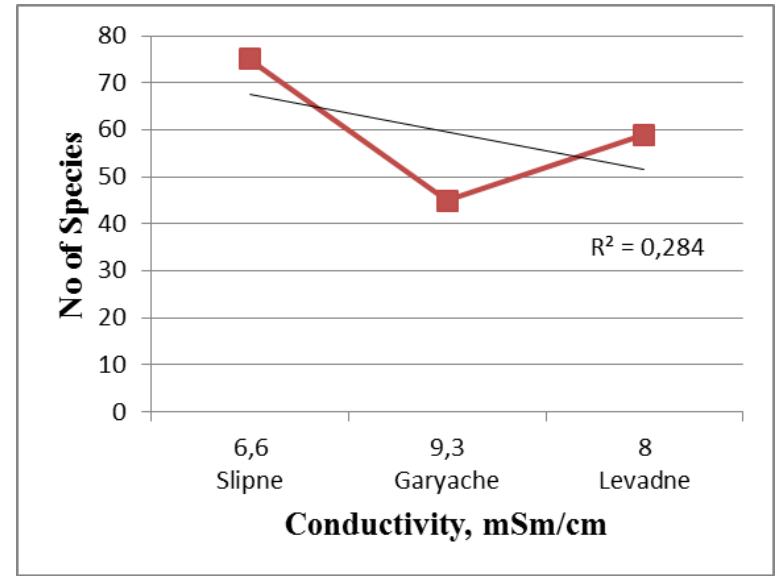

Figure 2b: Relationships between species numbers and water conductivity in the lakes: B - Slipne, Garyache, Levadne. 
The highest average biomass of phytoplankton is registered in lake Slipne (3.86 g/l), the lowest in lake Ozero (1.11 g/l) (Figs. 3a and 3b).

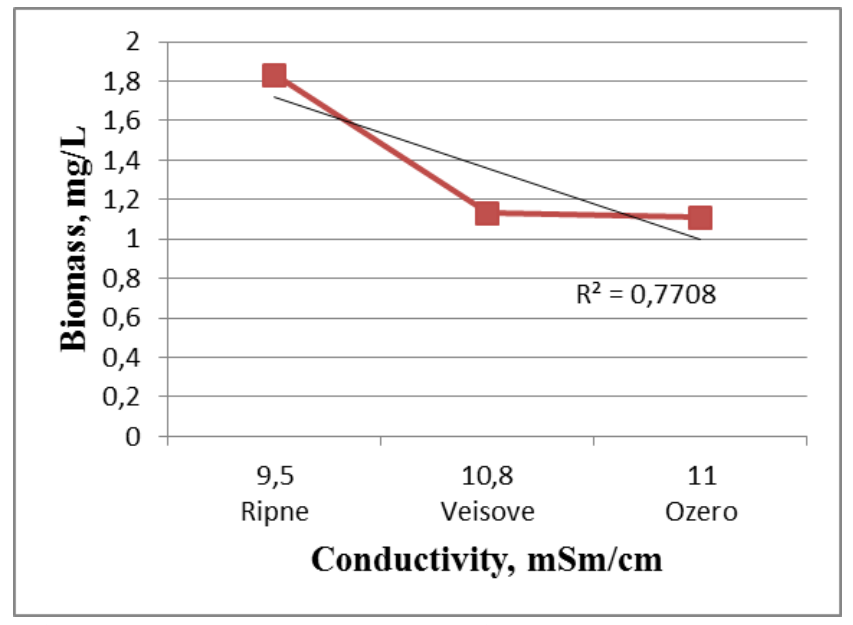

Figure 3a: Relationships between phytoplankton biomass and water conductivity in the lakes: A - Ripne, Veisove, Ozero.

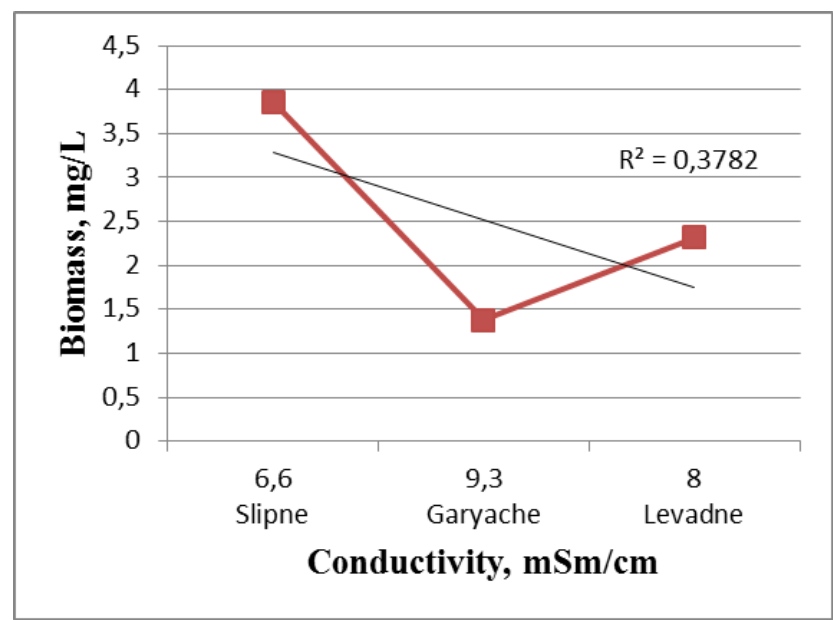

Figure 3b: Relationships between phytoplankton biomass and water conductivity in the lakes:

$$
\text { B - Slipne, Garyache, Levadne. }
$$

\section{DISCUSSION}

In the course of our analysis we found an inverse relationship between conductivity, species richness and phytoplankton biomass across two gradients that divide the lakes of the "Slavyansky Resort" into two: the first gradient groups lakes Ripne, Veisove and Ozero, whilst the second gradient groups lakes Slipne, Garyache and Levadne.

The species number is proportional to taxonomic diversity, because more saline waters have fewer taxa than freshwater (Figs. 2a and 2b). Salinity is the major regulating factor, in relation to the total number of species in algal communities (Naumenko and Makeeva, 2011; Barinova et al., 2010a, 2011; Klymiuk et al., 2014), in the abundance and biomass of phytoplankton (Krupa et al., 2014), and in the composition of the dominant species (Naumenko and Makeeva, 2011; Barinova et al., 2010b, 2011). 
Biomass characterizes the activity of creation of organic matter in the ecosystem, so hence an increase in salinity within an ecosystem results in not only reduced diversity, but also reduces the productive capacity (Figs. $3 a$ and $3 b$ ).

The influence of the right tributary of the paleoriver in the landscape is visible only in lake Ripne, with further movement of water masses through the alluvial layers in lake Veisove and lake Ozero only being detected by a consistent increase in the conductivity from lake Ripne, via lake Veisove to lake Ozero (Fig. 1). The intermediate tributary has its origin above lake Slipne (identified with the help of bio-indication from planktonic algae (Klymiuk et al., 2014), with ground flows into lake Garyache, and then lake Levadne. Among the lakes in the line Slipne - Garyache - Levadne there is no clear increase in water conductivity, suggesting that the intermediate tributary is not an important one in the regulation of water conductivity. In contrast, the left tributary of the paleoriver is visible in the modern landscape in spring, during which period it is also likely to have superficial connections to lake Veisove. As a result, all tributaries that join lake Levadne originate the river Kalantaevka. It should be noted that a significant complication in assessing the impact of inflows on the chemical composition of the lakes is the presence of a fault under the karst lakes Garyache, Veisove, and Ripne (Popkov et al., 2005) and as a result the presence of additional brine-rich waters. It is also important to understand that during the underground exchange between lakes, water passes through non-uniform layers of alluvium and becomes enriched with minerals to varying degrees (mineralization of alluvial waters range from one to $150 \mathrm{~g} / \mathrm{l}$ (Popkov et al., 2005)). Thus, in the current landscape most of the movement of water is not visible, except through measuring the activities of these lakes ecosystems.

The park Authorities are trying to improve the mineralization and production of therapeutic mud through the addition of salt to lake Slipne. These attempts may be successful in the case of short-term necessity, especially in the absence of seasonal surface runoff. However, this study indicates that this this effect is likely to be short-lived, because of the regular inflow of freshwater into the lake from the palaeobasin. The influence of groundwater flow can be so significant, even during low-water periods, that the addition of salt to the water body is likely to make little difference. Instead, it may be better to increase salinity via a reclamation work which aims to reduce at least part of the groundwater flow (by gutters and ditches) above the lake, whilst at the same time increasing the inflow of salty water. Although the application of this technique is also seasonal, compared with the first method it will achieve a more lasting effect on therapeutic mud production. In any case, because the production of medical mud is a long-term process, any effects such as those described above are likely only to be of short duration, so the effect of the impact from the purpose of increasing the quantity of medical mud will be scarcely noticeable.

\section{CONCLUSIONS}

A decrease in species richness and biomass of planktonic algae has been found with increasing water salinity of the wetlands in the RLP "Slavyansky Resort". The ecosystem productivity is reduced with a significant increase in mineralization, which in turn affects the speed of formation of therapeutic mud. When there is insufficient salinization, the formation of medical mud is impossible due to the nature of the process' chemistry. Mineralization of the lakes depends on the presence or absence of underlying karst fracture, and on the flow direction of underground paleoriver tributaries, which are often invisible in the landscape, but which can be identified either via bio-indicators from the algal communities, or via the chemical composition of the water. Any activities in relation to transforming the water quality of these lakes should take into account the peculiarities of their groundwater supply if they are to be successful. 


\section{ACKNOWLEDGEMENTS}

We thank our colleagues from the "Slavic hydrological regime-operational station" JSC Ukrprofzdravnitsa for their assistance in the historical data collection. This work was partly supported by the Israeli Ministry of Absorption. 


\section{REFERENCES}

1. Barinova S., Tavassi M., Glassman H. and Nevo E., 2010a - Algal indication of pollution in the Lower Jordan River, Israel, Applied Ecology and Environmental Research, 8, 1, 19-38.

2. Barinova S. S., Yehuda G. and Nevo E., 2010b - Comparative analysis of algal communities of northern and southern Israel as bearing on ecological consequences of climate change, Journal of Arid Environments, 74, 765-776.

3. Barinova S. S., Nevo E. and Bragina T. M., 2011 - Ecological assessment of wetland ecosystems of northern Kazakhstan on the basis of hydrochemistry and algal biodiversity, Acta Botanica Croatica, 70, 2, 215-244.

4. Barinova S., Klymiuk V. and Lyalyuk N., in press - Ecology of phytoplankton in the Regional Landscape Park “Slavyansky Resort”, Ukraine, Applied Ecology and Environmental Research.

5. Globan B., 1987 - Unified methods of investigation of water quality, Part 1, Methods for chemical analysis of water, 1, Basic methods, Moscow, Russia: Printing house of the Administrative office of the secretariat of the CMEA, 1244. (in Russian)

6. Hammer U. T., 1986 - Saline Lake Ecosystems of the World, V. 59, Dordrecht, Netherlands: Springer Science and Business Media, 616.

7. Holopov A. P., Shashel V. A., Perov U. M. and Nastenko V. P., 2002 - Fangotherapy, Krasnodar, Russia: Newspaper publishingb "Periodicals of Kuban”, 284. (in Russian).

8. Klymiuk V., Barinova S. and Lyalyuk N., 2014 - Diversity and Ecology of Algal Communities from the Regional Landscape Park "Slavyansky Resort”, Ukraine, Research and Reviews: Journal of Botanical Science, 3, 2, 9-26.

9. Klymiuk V. and Barinova S., in press - Phytoplankton communities in ecological assessment of lacustrine ecosystems in the wetland "Slavyansky Resort", Ukraine, Journal of Wetlands Biodiversity.

10. Krupa E., Slyvinskiy G. and Barinova S., 2014 - The effect of climatic factors on long-term dynamics of phytoplankton, zooplankton and macrozoobenthos of the Balkhash Lake (Kazakhstan, Central Asia), Advanced Studies in Biology, 6, 3, 115-136.

11. Kurulenko S. S. and Tretyakov S. V., (eds), 2008 - Donbass reserved. Research and Information Guide Atlas, 2nd edition, Donetsk, Ukraine: Donetsk Branch of State Institution "State Ecological Institute of the Ministry of Environment of Ukraine", 67-69, 125-126. (in Ukrainian)

12. Lyalyuk N. and Klymiuk V., 2011 - Phytoplankton of salt lakes of Slavyansk (Ukraine), Algology, 21, 3, 321-328. (in Russian)

13. Naumenko Y. V. and Makeeva E. G., 2011 - The algae of the saltish Listvenki Lake (area of "Podzaploty", Reserve "Khakassky"), The flora of Asiatic Russia, 2, 8, 28-33. (in Russian)

14. Popkov A. I., Morenko U. I. and Popkovskaya L. G., 2005 - The development of processes of flooding and karsting in the territory of Slavyansk, Donetsk region, Artemovsk, Ukraine: Foundations of GRGP “Donetskgeologiya”, 1-8. (in Russian)

15. Tsarenko P. M., Vasser S. P. and Nevo E., (eds), 2006 - Algae of Ukraine: diversity, nomenclature, taxonomy, ecology and geography, 1, Cyanoprocaryota, Euglenophyta, Chrysophyta, Xanthophyta, Raphidophyta, Phaeophyta, Dinophyta, Cryptophyta, Glaucocystophyta and Rhodophyta, Ruggell: A. R. G. Gantner Verlag, 716.

16. Tsarenko P. M., Vasser S. P. and Nevo E. (eds), 2009 - Algae of Ukraine: diversity, nomenclature, taxonomy, ecology and geography, 2, Bacillariophyta, Ruggell: A. R. G. Gantner Verlag, 413. 